\title{
Spatial and Temporal Dilemmas of Managers and Entrepreneurs. The Reconstruction of Neutralization Techniques
}

\author{
Waldemar Dymarczyk \\ University of Lodz, Poland
}

DOI: http://dx.doi.org/10.18778/1733-8077.16.4.03

\section{Keywords:}

Career; Managers;

Entrepreneurs;

Organizations;

Techniques of

Neutralization;

Narratives; Qualitative

Methods; Temporality;

Time; Space; Spatiality;

Guilt and Shame

\begin{abstract}
It is often assumed (in line with social expectations) that being a business manager and/or owner implies the feeling of omnipotence. Not only do organizational leaders run businesses, but they are also qualified to do so and are well-organized to physically and mentally cope with their duties. Thus, permanent (external and internal) pressure forces key organizational actors to use self-presentation strategies that meet social expectations.

Narratives of organizational leaders show that other aspects of their lives are subdued to the sphere of business activities or are even incorporated by it. One of the most dominant strategies is to present oneself as an inner-directed individual in control of one's career (a "self-made man" or "self-made woman"). At the same time, such an attitude results in "tensions" between irreconcilable roles or activities undertaken in various spheres of life.

These tensions are depicted in the paper. The author shows different types of neutralization techniques used by organizational leaders to overcome or mitigate these tensions. Eleven neutralization practices have been outlined. These techniques have been identified in the course of the nearly decade-long research into spatial and temporal dimensions of careers of managers and entrepreneurs.
\end{abstract}

Waldemar Dymarczyk, Ph.D., is an Associate Professor at the Department of Sociology of Organization and Management, Institute of Sociology, Faculty of Economics and Sociology, University of Lodz. His interests cover grounded theory, temporal and spatial dimensions of social life, visual sociology, sociology of propaganda, and sociology of organization and management.

email address: waldemar.dymarczyk@uni.lodz.pl 


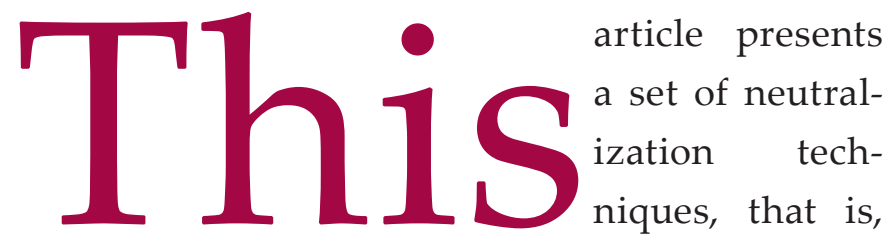

rationalizations-justifications applied by organizational leaders-managers and entrepreneurswhen they violate universally binding standards and consequently experience the feeling of guilt and shame. The list of these techniques was developed based on the data collected during the narrative and unstructured interviews collected as part of two research projects. The first one, conducted in the middle of the previous decade, studied the "temporal dimension of managerial careers" (Dymarczyk 2008; 2011; 2013), while the second one was implemented in 2010-2016 and focused on the "spatial dimension of managerial and entrepreneurial careers" (Dymarczyk 2015; 2018). In both cases, the primary objective was to reconstruct actors' organizational career patterns and their characteristic stages. In both research projects, it was possible to discover and describe different career patterns, their stages, and the broad context of their preconditions. In the course of the analysis, an additional theme transpired (was noticed by the author), that is, the use of the mentioned neutralization practices by the interlocutors. They appeared despite and in contrast to the dominant narrative form and style of organizational leaders. This narrative form and style of many personal accounts can be described as "self-ravishing presentations" aimed to expose organizational actors' successes and merits which allowed them to achieve, maintain, or strengthen their position in the organizational hierarchy.

In short, it is about presenting their career as a controlled and persistently implemented plan, as a personally "constructed career" (see: Savickas
2005; 2011; Domecka and Mrozowicki 2008). While listening to these narratives, one could get the impression that organizational actors can be defined as "self-made men" or "self-made women," which is not surprising. Firstly, organizational leaders are usually inner-directed and well-motivated individuals. Secondly, well-structured and credible self-ravishing presentations are a result of socialization which organizational leaders (usually) undergo in the process of long-term training, applying for and achieving higher positions in the organizational hierarchy.

Therefore, it was all the more surprising and at the same time challenging and worthy of special attention that interlocutors-usually after some time, due to the exhaustion of the repertoire of "ready-made narrative scripts"-discontinued self-ravishing presentations. Ready-made scripts were replaced by accounts of (usually enduring) role conflicts, that is, those between a successful businessman/businesswoman and a spouse, parent, partner, colleague, or member of the local community. At the same time, these accounts were accompanied by the abovementioned justifications-explanations, that is, neutralizations. Moreover, it is noteworthy that business actors subjected to pressure (system of rewards, penalties, regulations, promotion rules, ideology, etc.) must revise their views, motivations, and concrete actions to adequately fulfill their roles and at the same time "be at peace with themselves." In other words, they must perform permanent "identity self-work" (Konecki 2007). Reconciling the requirements of a "system" they are part of with those of other social worlds in which they live has its costs. This paper discusses one of the ways of dealing with these costs, that is, neutralizations. 


\section{Theoretical Considerations and Literature Review}

\section{Career from an Interactionist Perspective (with Particular Emphasis on the Context of Time and Place)}

Everett Hughes (1997:389) described his concept of a career as "a person's course or progress through life (or a distinct portion of life)" and in a more narrow sense as "a profession affording opportunities for advancement." He distinguished between the objective and subjective dimensions of a career. Hughes (1964:63) defined "the objective career as directly observable, measurable, and verifiable by an impartial third party." However, from a subjective point of view, "a career is the moving perspective in which the person sees his life as a whole and interprets the meaning of his various attributes, actions, and the things which happen to him" (Hughes 1964:63). In this paper, the author focuses primarily on the second point of view, the perspective of a social actor.

It should be emphasized that the problem of individual and group careers has always been an important issue in symbolic interactionism, and especially in the Chicago School. Obviously, the Chicago interactionists' approach is known not only for noticing the subjective dimension of a career. According to the Chicago School, social life cannot be understood without analyzing the context of time and space in which a social actor lives. In other words, Chicago sociologists assumed that "no social fact makes any sense abstracted from its context in social (and often geographic) space and social time. Social facts are located" (Abbott 1997:1152). For example, back in 1927, Frederic Thrasher described the gang career in a spatial context with a map of a network of brothels, residential hotels, businesses, et cetera. Clifford Shaw analyzed life histories of people who ran afoul of the law in his The Natural History of a Delinquent Career (1931) and The Jack-Roller: A Delinquent Boy's Own Story (1930). He showed the importance of an interactional field in "making a criminal," that is, the neighborhood and enabling a novice to practice under the supervision of an experienced criminal. In the organizational and institutional context, Howard Becker, using the example of a teaching profession, drew attention not only to the obvious - "vertical"-aspect of a career (understood as a movement across the hierarchical structure of a school) but also to the "horizontal" dimension, different positions at the same level of the hierarchy. The temporal aspect of a career was explicated by Thrasher and Clifford Shaw and others in the above-mentioned books. Shaw noted that a delinquent's career consists of a series of typical stages. Subsequent Chicago School representatives developed this topic. They spoke of periods, phases, or cycles and referred to the descriptions of careers of various social actors, for example, dancers (Cressey 1932), physicians (Hall 1948; Becker et al. 1961), or marijuana smokers (Becker 1973). At the same time, the career path does not usually resemble a simple and unproblematic, ascending line of promotions and status transitions. It might be full of numerous crises, conflicts, and dilemmas (Hughes 1971), incidents, intertwined circumstances, and turning points (Strauss 1977).

This paper is based on research that is characterized by, so to speak, "double" embeddedness in the Chicago School tradition. First of all, the very approach to a career implies focusing attention on its temporal and spatial dimensions. Secondly, since 
these dimensions are the main axes of interlocutors' reflections and narratives, both the interviewees and researcher focus on what has always been the key context for research and reflection of the "founding fathers" of the interactionist school and their followers.

\section{Guilt and Shame as a Source of Neutralizations}

As mentioned in the introduction, the dominant narratives were "self-ravishing presentations" that exposed interviewees' agency in shaping their careers. The researcher was especially interested in situations when the organizational actor was "breaking character," for example, when one of them said: "My family lives here, I see them only during the weekends, which is a bit unfair," while a female manager who has a lot of business trips and stays in different cities mentioned: "As I said before, I wanted to be more successful, but in the long run, spending time away from home, especially long business trips are destructive. To be fair, I have my family's support, but I feel that it isn't fair. That is why I have a guilty conscience." Thomas J. Scheff (1984) paid special attention to such cases (see also: Scheff and Ratzinger 1991; Konecki 2008). ${ }^{1}$ He pointed out that chronic overt shame can be present in an individual's life for so long that it becomes barely noticeable. Shame can

\footnotetext{
${ }^{1}$ From the perspective of symbolic interactionism, emotions do not only or primarily boil down to general responses to external stimuli. As McCarthy (1989:57) stated, "My feelings are social, that is, they are constituted and sustained by group processes. They are irreducible to the bodily organism and to the particular individual who feels them." In the context of emotions emphasized in this article, Susan Shott (1979) made an important contribution, namely, in her opinion, "role-taking emotions," and in particular shame (and empathy), are strongly associated with the social self. We cannot, for example, feel shame without taking into account the "generalized other." Guilt cannot embarrass us, even when nobody is around, if we do not feel social responsibility (see: Fields, Copp, and Kleinman 2006:158).
}

be ignored or overlooked thanks to two mechanisms: "bypassed shame" and "overt-undifferentiated shame." In the first case, the individual exhibits "unnatural" verbal behavior and gestures (e.g., obsessive, turgid, and emphatic thinking, talking, and acting) to avoid the feeling of shame, as in the quotation below:

[A spontaneous and highly emotional response to the interviewer's question: "How many children do you have?"]:

No, my children are already grown-ups, I've got no problems with them, anyway I've never had! [said very rapidly, emphatically-author's note]. They are very placid, they have good grades. What is more, they had to learn how to cook really early on. My son was 7 when he started preparing pork chops because he liked them.

The so-called "overt-undifferentiated shame" is associated with low self-esteem. In such a case, the individual's response could reveal confusion. S/he can be making pauses and use euphemisms:

I don't really remember what it means, what a normal [smile] home means... but I am a contemporary mom, mind you, who can do everything on her own [laughter], well... almost on her own [smile]...It's not the end of the world just because I leave for work.

Individuals have to cope with negative feelings, such as guilt and shame, to play an active role assigned to them and maintain a positive image of themselves at the same time. Thus, some problematic issues related to the physical (and sometimes mental) absence of actors from their friends and family revealed in some interviews required further explanations to maintain their positive image. We are referring to neutralizations. 


\section{Neutralizations}

Neutralizations are understood here primarily as interactional techniques applied both as part of a dialogue with the interaction partner(s) and the internal dialogue with the generalized other. They aim at preserving a positive image of oneself and presenting oneself in such a way that, despite the violation of a generally binding standard, a positive impression is given off (see: Goffman 1967). It is noteworthy that social actors occupying high-profile positions in the world of business have a limited scope of maneuver when it comes to their image. In this world, roles are relatively standardized, self-presentation scenarios are quite clear, while the definition of the situation leaves little space for negotiation. Face-saving is a strongly internalized necessity and neutralization techniques are useful whenever, in his/her opinion, a business actor commits a faux pas in his/her self-presentation (Goffman 1959; 1967). It is also noteworthy that organizational leaders are mostly people with high social competencies, including advanced communication and, of course, linguistic skills. Against this backdrop, it seems worthwhile to look at how these competencies are used for self-presentation and repair.

Two American sociologists, Gresham Sykes and David Matza (1957), proposed a neutralization theory largely in opposition to the then developed theories of deviant behavior (mainly social control theories and cultural theories) which served as a source of inspiration. The abovementioned sociologists developed their own, original concept. In their research into the juvenile delinquency environment, they reconstructed five neutralization techniques commonly used by criminals to justify their behavior, at least to a certain point. In oth- er words, these techniques help to avoid complete rejection of the universally binding social standard which has been violated and only temporarily "suspend" it. The denial of responsibility, denial of injury, denial of victim, condemnation of condemners, and appeal to higher loyalties ${ }^{2}$ are so common that the rationalizations described by Sykes and Matza can be classified as substantive theory. Later on, the theory was supplemented with additional, also commonly used techniques (Klockars 1974; Minor 1981; Coleman 1987; 2002; Lyman 2000; Nelson and Lambert 2001) such as emotional obfuscation, the denial of negative intent, claim to normality of the behavior, metaphor of the ledger, ${ }^{3}$ and similar rationalizations such as the claim of the relative acceptability of the behavior, appropriation and inversion, evidentiary solipsism, and defense of necessity.

The abovementioned neutralizations are used not only by criminals. They are triggered whenever an individual is at the crossroads between an official, largely conformist system of values accompanied by the normative system and a "subcutaneous," unofficial, and often deviant system of values which are followed in practice. There are well-documented examples of rationalizations reconstructed in environments very different from

\footnotetext{
${ }^{2}$ In short, these neutralizations can be described in the following way: "(D)enial of responsibility-negating personal accountability and breaking the link between oneself and one's actions. (D)enial of injury-claiming that no one was injured by one's actions, thus breaking the link between the act and its consequences. (D)enial of the victim-claiming that the injury inflicted was, in fact, retaliation or punishment, thus transforming the victim into the wrongdoer. (C)ondemnation of the condemners-attacking one's critics, claiming that their own condemnation is unjustified. (A)ppeal to higher loyalties-highlighting one's conflicting roles and adherence to higher principles in choosing one action over another" (Bryant et al. 2017:4).

${ }^{3}$ The metaphor of the ledger is best described as follows: "I've definitely done more good than evil. These few infamous actions will not outweigh my merits anyway. I have a credit to use."
} 
those studied by Sykes and Matza. For example, William C. Brennan (1974) described neutralization practices used by women who decided to have an abortion, as well as medical staff performing it. Pregnant women who decided to terminate their pregnancy justified their decision by the existence of different types of restrictions and lack of support in terms of welfare or additional assistance especially for the poor or excluded women (in the categorization of Sykes and Matza, denial of responsibility). They also referred to the costs of having an unwanted baby (appealing to higher loyalties). In turn, representatives of medical staff, that is, physicians and nurses justified their consent to perform an abortion by negating the human subjectivity of the embryo, that is, through its depersonalization (denial of injury) and the use of such abortion techniques as vacuum aspiration whose visual effect is only a mass of used, soiled tampons (denial of injury). In her research into the environment of young physicians, Dominika Byczkowska (2006) reconstructed rationalizations corresponding to the rule of the denial of responsibility. The most frequent justification for accepting bribes was the conclusion that the current system of managing and financing national healthcare is "sick" and it thus prompts unethical behavior. Bribery was also justified by appeals to higher loyalties, for example, to the need to provide for a decent life of a physician's family.

Speaking of the group of managers and entrepreneurs studied by the author, let us refer to the wellknown research conducted by American sociologist James W. Coleman (1987; 2002). He analyzed cases of unethical and criminal steps taken by the white-collar staff and described a number of neutralizations accompanying such deeds. Thus, the most frequently employed rationalization tech- niques include the "denial of the necessity of the law," a technique based on a statement "everybody else is doing it" and the "claim of entitlement." The popularity of the denial of the necessity of the law is explained below. Namely, managers' efficiency, which is usually reflected in generated profits, is the raison d'être and basis for the evaluation of their performance. Working under constant pressure, in a competitive environment, business managers are tempted to use shortcuts to achieve measurable results in no time. Therefore, managers and entrepreneurs in general frequently face a dilemma of whether to follow the rules, adhere to all standards and formal arrangements, or break legal constraints to satisfy role-related expectations. The pressure an individual is subjected to encourages the use of the denial of the necessity of the law technique.

The approach "everybody else is doing it" is applied by managers and entrepreneurs who comprise a relatively homogeneous group. They usually belong to similar social strata, have similar education, follow similar consumption patterns, et cetera. Most importantly, they operate in a similar milieu which values competition and success. Thus, when actors observe behavior that violates applicable laws or morals, they are willing to do likewise, especially when they can expect rewards for the results achieved this way. The claim of entitlement (to violate the norms) seems understandable given the high status of managers and entrepreneurs. This status stems, among others, from good financial standing and high prestige of business managers, as well as advanced competencies and personal qualities necessary to effectively fulfill this role. Therefore, the noblesse oblige rule can easily be replaced with the noblesse privilege rule. 


\section{Data and Methods}

The analyzed material comprises 44 narrative and unstructured interviews with business people, managers of various managerial levels (from operational to strategic levels) working in medium and large profit-oriented organizations, as well as entrepreneurs (owners or co-owners of businesses). The group of interviewees is diverse in terms of age and professional experience. The interviews were conducted as part of two research projects. The first one was carried out in the mid-2000s and focused on "the temporal dimension of managerial careers" (Dymarczyk 2008; 2011; 2013), while the second one was carried out in 2010-2016 and it studied "the spatial dimension of managerial and entrepreneurial careers” (Dymarczyk 2015; 2018).

I applied the descriptive version of grounded theory in my analysis (Strauss 1987; Strauss and Corbin 1990; 1994; 1998). The procedure of data collection and analysis recommended by the founders of grounded theory enables one to preserve the context of discovery (serendipity), ${ }^{4}$ which is one of the main advantages of the exploratory research type. The abovementioned projects are undoubtedly exploratory in their nature. Due to an exceptionally flexible approach to the research problem, subsequent research stages, and collected material, the researcher has a chance to discover phenomena that have previously been

\footnotetext{
4 "'Serendipity' means an unexpected discovery or the ability to make fortunate and unexpected discoveries. The term in English was coined by English writer Horace Walpole (1754). He constructed this neologism based on an old Persian fairy tale 'The Three Princes of Serendip.' The princes made permanent discoveries of things they were not in quest of. Serendip is an old name for the island of Ceylon (currently Sri Lanka). The name is derived from the Sanskrit 'Simhaladvipah' or the Island of Lions" (Konecki 2005:27).
}

unnoticed or ignored. This is undoubtedly true of reconstructed neutralization practices.

\section{Findings}

\section{Time- and Space-Related Tensions and Their Neutralization}

Achieving an often desired managerial position ${ }^{5}$ is a very important stage in the career of an actor who decided to pursue his/her ambitions in the business world. The time devoted to work so far is extended based on the assumption that the number of hours allocated to work (primary activity) depends on organizational pragmatics (i.e., it is worth spending time and effort on that which brings the desired outcome). Interviewees often mention that departing from everyday routine and undertaking ad hoc activities is an "objective necessity":

Typical workday? It's different...No two days are identical, because each customer is different and the duration of these meetings is different.

I'm result-oriented. There's no rigid day schedule. It must be done, that's all. It doesn't matter whether I work seven or twelve hours.

My company is "pure" capitalism. It doesn't matter if I'm at work eight hours or more...I can't ignore what is going on.

A task-oriented approach to work, as illustrated above, has to result in tensions between the world

\footnotetext{
5 "Temporal" neutralizations were reconstructed only on the basis of interviews with managers. Entrepreneurs were invited only to the next project regarding the spatial dimension of careers.
} 
of work and other worlds in which the social actor participates. Long hours at work, at the expense of family and friends, must be explained and justified so that a manager or entrepreneur can focus on their primary activity. Therefore, narrators often feel compelled to use different types of strategies and justifications-rationalizations, that is, neutralizations, to mitigate (or avoid) temporal tensions, especially when the feeling of guilt and shame could prevent or hinder efforts for the benefit of an organization (and their career).

Please find the list of identified neutralizations below. ${ }^{6}$

\section{Neutralization No. 1. Time Does Not Equal Time, That Is, the Scarce Quantity of Time Devoted to One's Family Is Compensated for by the Quality of That Time}

For example, my temperament and the way I spend my spare time makes me a companion for my daughters. They can always go swimming with me, play volleyball, badminton, ride a horse, play tennis, roller-skate, ride a bike, right?...What is more, well, I think that the quality of contact is decisive... Of course, we have them, but I see the same problems, or problems of similar intensity, in families in which husbands come back home at four o'clock sharp. And this is, as I say, a certain quality of time and, and this is what matters.

This neutralization seems to be an exemplification of the rationalization described by Sykes and Matza as the "denial of injury." According to the interviewees, nothing is wrong. One can compen-

\footnotetext{
${ }^{6}$ Neutralizations reconstructed during the first "temporal" research project.
}

sate for lost time with the intensity and special quality of contact with loved ones.

Neutralization No. 2. Nature and/or Traditional Rules, That Is, Reference to (Traditionally Understood) Complementary Male and Female Roles

My wife was taking care of all household chores. She was raising our son. I was working. It's funny, it's sad that I don't remember birthdays, wedding anniversaries, something else, but I remember the phone number of a business partner in Germany...Well, but that's life.

In the case of such statements, it is difficult to find a clear reference to the previously mentioned neutralizations. The most similar rationalizations seem to be the "claim to normality of the behavior" and the rule of "everybody else is doing it."

Neutralization No. 3. Everyone Is Going to Be Fine, That Is, the Belief in Exceptional Maturity and Self-Sufficiency of Family Members (Children) as a Justification for a Limited Amount of Time Contributed to Family Life

[An interviewee's spontaneous response to the question about the age of her children which was quoted earlier]:

No, my children are already grown-ups, I've got no problems with them, anyway, I've never had!

The "denial of injury" seems to be the most comparable neutralization. There are no obstacles to fulfill one's tasks. Everyone is mature enough and focused on self-fulfillment independently of the actions taken by others. 
Neutralization No. 4. I Am Better, That Is, Downplaying the Role of a Spouse, Presenting Him/Her as a Person Who Cannot Provide for a Family. Therefore, an Interviewee Is a Guarantee of the Family's Financial Security

I married a man who is rather poorly organized and rather poorly, poorly org... organized and unresourceful. I don't know, that's what I chose [put in bold by the author]...Well, there simply were situations when I simply wanted to quit my job and, I don't know, go into the unknown. No matter what. It would have been very difficult since my husband is unresourceful. He runs his small private business. But, it's... He earns peanuts. It's me who is the pillar.

The "claim of entitlement" seems to be the neutralization corresponding with the above statements. Depreciation of partners does not necessarily result from the interviewees' ill will. Well, "the breadwinner has her rights."

\section{Neutralization No. 5. Everyone Does Their Own Bit, That Is, the Lack of Temporal Tensions Is Justified by the Fact that Both Partners Are Equally Involved in Their Work}

$\mathrm{Hmm}$, as far as family matters are concerned, I've got no idea whether...Oh, you see. Well, if you think about it now, hmm... Perhaps it [the conflict-author's note] does not appear that often because my wife had that great job [she is also a manager-author's note], so she moved to Warsaw and there was no problem with that at all...She works a lot as well.

In this case, references can be made to such techniques as the "denial of injury" or the "denial of responsibility," as well as an original mode of argu- mentation developed based on cultural changes in understanding the role of partners.

\section{Neutralization No. 6. A "Purchased" \\ Exteriorization of Responsibility, That Is, Mitigating Temporal Tensions with the Help of a Third Party}

We have this lady, a girl, who collects our child from kindergarten, let's say about 3 p.m., and then stays with him till 5 p.m., until my wife comes back from work. Because my wife works on site. So, this girl stays with my child for two hours. Then my wife comes back from work and everything is just fine... During a holiday season, like now, our child is at his grandma's, so there is no problem either.

According to interviewees, financial and social resources allow them to sort out problems related to the lack of time which could, and should, have been spent with family members otherwise. This rationalization, probably used at all times, has not been explored yet. At the same time, there are indirect references to the techniques of the "denial of injury" and "denial of responsibility." Everything seems to be fine since caregivers are competent and potential problems are minimal.

\section{Neutralization No. 7. Technology Helps, or the Ability to Remotely Control Important Family and Personal Issues}

We spend a lot of money on phone calls. We text because we stay in touch every single day, even for a quick while...This is what keeps us together.

Internet and mobile phone services have become widespread and remote contact has become the staff of life. Undoubtedly, it enables us to maintain rela- 
tions with relatives, but it is often treated as a user-friendly "artificial limb" which only imitates real, face-to-face encounters with people we care about. Similarly to the previous neutralization, this technique seems to represent the "denial of injury."

\section{Neutralization No. 8. An "Appeal to Higher Loyalties," That Is, One Should Provide for a Better Life for the Loved Ones (Children)}

My private life starts, let's say, at 8 p.m., when I can fully devote my time to my daughter. I haven't got much time, and during the school year, I see her only in the mornings when she's getting ready for school... It's all a matter of getting used to things. If it weren't for some sacrifices of mine, I wouldn't be able to provide her with everything she has today and will have later on in the future.

This neutralization appeared in two narratives. It is probably not by chance that these accounts were presented by people who managed relatively small businesses extremely sensitive to changes in the economic situation. At the same time, these were "promoted" people whose position depended not so much on exceptional skills or qualifications, but rather on devotion to work. Therefore, it is not surprising that, as parents, they want to secure their children's "starting position" so that they do not have to make sacrifices and experience concerns their parents have to face. ${ }^{7}$

My research into the spatial dimension of careers ${ }^{8}$ (some of the data collected during the previous project were used) also highlights the issue of neutral-

\footnotetext{
${ }^{7}$ Reconstructed "temporal" neutralization practices, see also: Dymarczyk 2008; 2011.

${ }^{8}$ 2010-2016-a project called "Spatial dimension of managerial and entrepreneurial careers" (Dymarczyk 2015; 2018).
}

ization. It is noteworthy that most "temporal" rationalization techniques directly refer to situations in which the spatial (physical and/or psychological) distance creates tensions which at the same become a pretext for explanations to mitigate them.

The most recent research has resulted in further examples of explanations aimed at mitigating tensions between the normative system and everyday practices.

\section{Neutralization No. 9. Special Role of Leisure \\ Destinations or the Ability to Ensure/Rebuild \\ Close Relations with Family Members Thanks \\ to Spending Time with Them in a Favorable \\ Environment}

\begin{abstract}
I do my best to make sure that vacations or even a couple of days off are inspiring. I mean, so that my wife and kids enjoy this time. It's therefore usually an option of going somewhere to a distant place and staying there in a comfortable place. For example, some islands or South America. Diving, swimming, some rafting, or something like that. Long story short, I devote myself to the company too much not to compensate for that later on...That helps us to build relations, enjoy life. It gives a new impetus. We get our batteries of family emotions recharged. Also, the kids can spend time with their father and see that he isn't that useless [laughter].
\end{abstract}

This neutralization, as well as its twin neutralization mentioned above (neutralization No. 1 "Time Does Not Equal Time"), is an exemplification of rationalization called the "denial of injury." The narrator claims that lost time can be compensated for by the time spent in a unique place. The interviewee also applies Coleman's neutralization described as the "claim of entitlement" ("I devote myself to the 
company too much not to compensate for that later on").

\section{Neutralization No. 10. My Home Is My Castle; Meaning, I Am Absent from Home, but My Home Is My Family's Safe Haven}

I spend a lot of time away from home, sometimes really a lot. However, I made sure that home was always there...It's important that when we meet, everything that allows us to live normally is available. Good mood and relations are important, but they also depend on the fact that the house is cozy, that it isn't an adapted house, but a house in which it is easier to build such relations. Because me, us... my loved ones deserve that [put in bold by the author], they deserve to feel comfortable at home, so that some crap doesn't spoil our comfort. I work hard to make everything work.

The above neutralization is also based on the belief that damage caused by long-term family separation could be compensated for by special conditions in which family members meet. Both interviewees seem to be convinced that "they deserve that" because of a special role they play.

\section{Neutralization No. 11. The Quality of Contact} Does Not Depend on Location, That Is, When You Have Resources, Good Relations Can Be Built/ Maintained Regardless of a Specific Location/ Space [see neutralization No. 1. "Time Does Not Equal Time" and neutralization No. 5. "Everyone Does Their Own Bit"]

Actually, it doesn't matter where we are. The world is small, isn't it? And this is a fact [with emphasisauthor's note]. We can organize holidays, birthdays, name days anywhere, yeah. It is even very interest- ing. Besides, this is not unusual nowadays...Well, of course, we do have some sentiments such as Christmas eve and so on... All of that can be arranged when you have the will and resources...We even persuaded my parents once [put in bold by the author] and it was OK. So, there are different options in the world, all you need is the right attitude.

This neutralization technique is the opposite of the previous rationalization (No. 9). The author of these statements rejects the concept of the importance of the home as a safe haven understood as a specific meeting place and instead opts for the unspecified "everywhere." Besides, his conviction about the normality of this type of practice is supported by the belief that "everybody else is doing it."

\section{Discussion}

If we take a critical look at what has been written earlier, it is worthwhile to reflect on two (interrelated) issues that may raise questions or doubts.

To begin with, an attentive reader may ask whether neutralizations used by managers and entrepreneurs are not just useful rhetorical tricks. In other words, are organizational leaders not only using their linguistic, interactive, and cultural competencies trying to make a positive impression on their interlocutors and present themselves as reasonable people in control of their careers and issues of concern to them? To put it bluntly, are these neutralizations merely tools of the presentation of self? In some cases they certainly are. All the more so since self-presentation scripts used by organizational actors are usually prepared in advance, socialized, and honed earlier. Does it not remind us of the case of a criminal who credibly plays the role of a wrongly accused person in court, having been instructed 
by other villains to do so? Similarly, has a financier living beyond his/her means at the expense of his/ her clients not been instructed by older and more experienced financial tycoons how to deal with this problem? Thus, an appropriate and "professional" use of a neutralization technique is certainly a suitable way to maintain one's face and defend one's interests. However, not infrequent, spontaneous, and surprisingly emotional utterances indicate the authenticity of experiencing certain problems or moral dilemmas, the feeling of shame, and the need to neutralize it. This is evidenced by a spectacular example of the response of the interviewee who has already been quoted twice (neutralization No. 3) or the slightly less dramatic account of another interlocutor about her feckless husband (neutralization No. 4). These are extremely revealing utterances. According to Scott Grills and Robert Prus (2019:208), "interactive emotional episodes" are of paramount importance when it comes to understanding the process involving an actor, an organizational actor in particular. It is also noteworthy that a conscious choice of a ready-made script and authentic expression of emotions do not have to be in contradiction with each other.

Secondly, it is important to remember that, as interviewees have repeatedly stressed, becoming an organizational leader is usually a lengthy and costly process in terms of time, as well as a moral and emotional experience. The awareness that "the capital" has been poorly invested could be unbearable. Hence, one should not be surprised to hear often emphatic assurances of the relatively smooth coexistence of the worlds in which the social actor participates. Incidentally, the process of becoming an important organizational actor might resemble the process of becoming an inmate of the total institution described by Goffman (1961). Speaking of the early career, interviewees mainly mention costs, for example, cumbersome and long business trips, low salaries, time-consuming training sessions and meetings, and even mortifying experiences. In Goffmanian terms, this is a highly costly period of primary adjustment which mostly consists of transforming the self and moral degradation. It also serves as a precondition to forming a new concept of the self in line with the organization's norms and values. Subsequently, the process of secondary adjustment begins. Not only is the actor aware of the rules of organizational life, but s/he has also learned how to make use of knowledge and skills. At this stage, the rhetoric of "costs" is complemented or replaced by the rhetoric of "benefits." Let us not forget that, as a rule, the most passionate responses are elicited not so much by the awareness of the costs incurred, but by the fear of losing the benefits gained or recognition that sacrifices made so far "have not been worth the effort." Neutralizing negative feelings or avoiding them can be key to protecting the " $\mathrm{I}$ " of an organizational actor.

\section{Conclusions}

It is not easy to discover neutralization techniques. Interlocutors/interviewees usually strive to present a coherent and consistent story and present themselves as individuals who "know what they are doing" and control the course of events. It is especially true of key organizational actors who are well-socialized. They are mostly inner-directed individuals who are pursuing a career pattern typical of "self-made men"|"self-made women" (see: Dymarczyk 2011:242-248). They make sure that they "do not break character." A honed and frequently practiced narrative is a challenge for the researcher. Paradoxically, it also creates opportunities. The researcher needs to spot and interpret the "crack" in 
the narrative and an instance of "getting out of the role." However, as has already been mentioned, this is often difficult because organizational leaders are usually professionals in managing their image. It is also difficult to define the norms of conduct for the researcher and interlocutor. Entrepreneurs and professional company managers represent a relatively new class in Poland. Thus, it is not always clear which catalog of rules and norms of conduct should be applied in the case of this group.

Secondly, and this is related to the previous issue, social expectations, and assessment of behavior and actions of company leaders change rapidly. For example, during the period of Poland's transformation (the 1990s), there was a general agreement that all the available time and energy could be devoted to entrepreneurial and/or managerial tasks. In the subsequent decade, this belief was maintained, although there were critical opinions about the managers' unidimensional version of life and professional career. However, since the year 2000, in the era of late modernity, post-materialistic values and "lifestyles" have been cherished and they indicate reasonable life and career management (see: Jacyno 2007). This is by no means unique in the context of global changes. On the other hand, the pace of these changes is extraordinary. In Poland, they affect not only subsequent cohorts but also each of the cohorts individually. Therefore, when reconstructing neutralizations, one should be careful about the assessment of an utterance when deciding whether it is indeed an indication of a dilemma and what is the meaning of this dilemma. Dynamic changes within entire communities often result in anomy and it is not clear what is the norm (Durkheim 1951; Merton 1968). On the other hand, it can be assumed that certain temporal and spatial dilemmas are common in a globalized business world. As a result, the re- constructed neutralizations can be universalistic in their nature, but the local context should be kept in mind.

Assurances about the unproblematic or at most slightly problematic temporal-spatial coexistence of the "business world" and "family life" were quite common both in the first ("temporal") and most recent (spatially-oriented) studies. These utterances were emotional and spontaneous (not solicited by the researcher's questions). This may indicate that a dispute between two spheres of life is more widespread than the narrators would like to notice (or admit). It could perhaps be explained by the (conscious or unconscious) desire to maintain one's face. This is the face of a person capable of maintaining control over various spheres of life. It is precisely due to the abovementioned spontaneity and emotionality that getting out of the role is observed. On the other hand, such responses make the actor look credible in the eyes of the interlocutor. They present him/her as a reflective social life participant who is trying to reconcile the requirements of his/her social worlds.

The list of presented neutralizations is quite extensive, which is understandable since managers of businesses affected by market competition are subject to constant stress and (very often) temporal tensions. The need to reconcile different roles, each of which can fill the whole day, is conducive to launching various types of protective strategies, that is, neutralization techniques.

Most of the identified rationalizations exemplify the techniques described by Sykes and Matza, as well as their followers. However, some of them, for example, the fifth and the seventh neutralization techniques, are unique. Both neutralizations derive 
from social and technological advancements typical of late capitalism or postmodernism, as some would say. Neutralizations help to deal with the existing and fluctuating challenges faced by an individual immersed in everyday life. It is noteworthy that from an interactionist perspective neutralizations are of great importance for maintaining a sense of continuity of the biography of a social actor (Strauss 1977:139-149). Neutralizations seem to be very useful nowadays. On the one hand, there still exist fixed social expectations of certain social roles and asso-

\section{References}

Abbott, Andrew. 1997. “On Time and Space: The Contemporary Relevance of the Chicago School." Social Forces 75(4):11491182.

Becker, Howard S. 1973. Outsiders: Studies in the Sociology of Deviance. New York: Free Press.

Becker, Howard S. et al. 1961. Boys in White: Student Culture in Medical School. Toronto: University of Chicago Press.

Brennan, William C. 1974. "Abortion and the Techniques of Neutralization." Journal of Health and Social Behavior 15(4):358365 .

Bryant, Emily et al. 2017. "Techniques of Neutralization and Identity Work among Accused Genocide Perpetrators." Social Problems 65(4):1-19.

Byczkowska, Dominika. 2006. “Solidarność zawodowa jako wynik socjalizacji wtórnej. Na przykładzie zawodu lekarza [Professional Solidarity as a Result of Secondary Socialization: The Example of the Physician's Profession]." Przeglad Socjologii Jakościowej 2(1):88-110.

Coleman, James W. 1987. "Toward an Integrated Theory of White Collar Crime." American Sociological Review 93(2):406-439.

Coleman, James W. 2002. The Criminal Elite: The Sociology of White-Collar Crime. New York: St. Martin's. ciated behavior patterns (in this case, typical of an organizational leader/decision-maker). On the other hand, there exist challenges posed by "new" rules of reconciling professional and family life, as well as purposeful and balanced management of one's career. Neutralization techniques serve as "tools" that make "changes" possible, although it must be admitted that, in principle, this "tool" is more of petrification of the definition of the role of a manager and/or entrepreneur. At least this is true of Polish reality.

Cressey, Paul G. 1932. The Taxi-Dance Hall: A Sociological Study in Commercialized Recreation and City Life. Chicago: University of Chicago Press.

Domecka, Markieta and Adam Mrozowicki. 2008. "Robotnicy i ludzie biznesu. Wzory karier zawodowych a zmiana społeczna w Polsce [Workers and Business People. Patterns of Professional Careers and Social Change in Poland]." Przeglad Socjologii Jakościowej 4(1):136-155.

Durkheim, Emile. 1951. Suicide: A Study in Sociology. Glencoe, IL: Free Press.

Dymarczyk, Waldemar. 2008. Temporalny wymiar karier menedżerskich [Temporal Dimension of Managerial Careers]. Katowice: „Śląsk" Wydawnictwo Naukowe.

Dymarczyk, Waldemar. 2011. “It Is Only 24 Hours a Day-Neutralizations Are Necessary. Temporal Dilemmas of Managers." Polish Sociological Review 173(1):97-105.

Dymarczyk, Waldemar. 2013. “Gender Perspective and the Temporal Aspect in Managerial Careers: Male and Female Views of Time." Polish Sociological Review 182(2):239-254.

Dymarczyk, Waldemar. 2015. “O polifoniczności badania wymiarów kariery. Naturalna historia badania [Polyphonicity in Studying Career Dimensions. The Natural History of the Study]." Rocznik Lubuski 41:145-155. 
Dymarczyk, Waldemar. 2018. Przestrzenny wymiar karier menedżerów i przedsiębiorców [Spatial Dimension of Careers of Managers and Entrepreneurs]. Lodz: Wydawnictwo Uniwersytetu Łódzkiego.

Fields, Jessica, Martha Copp, and Sherryl Kleinman. 2006. "Symbolic Interactionism, Inequality, and Emotions." Pp. 155178 in Handbook of the Sociology of Emotions, edited by J. E. Stets and J. H. Turner. New York: Springer.

Goffman, Erving. 1959. The Presentation of Self in Everyday Life. Garden City, NY: Anchor Books.

Goffman, Erving. 1961. Asylums. New York: Doubleday/Anchor.

Goffman, Erving. 1967. Interaction Ritual: Essays in Face-to-Face Behavior. Chicago: Aldine.

Grills, Scott and Robert Prus. 2019. Management Motifs. An Interactionist Approach for the Study of Organizational Interchange. Cham: Springer.

Hall, Oswald. 1948. "The Stages of a Medical Career." American Journal of Sociology 53(5):327-336.

Hughes, Everett Ch. 1964. Man and Their Work. Glencoe, IL: Free Press.

Hughes, Everett Ch. 1971. The Sociological Eye. New Brunswick: Transaction Book.

Hughes, Everett Ch. 1997. "Careers." Qualitative Sociology 20(3):389-397.

Jacyno, Małgorzata. 2007. Kultura indywidualizmu [The Culture of Individualism]. Warsaw: Wydawnictwo Naukowe PWN.

Klockars, Carl B. 1974. The Professional Fence. New York: Free Press.

Konecki, Krzysztof T. 2005. "Teoria ugruntowana a kontekst odkrycia. Naturalna historia pewnego badania [Grounded Theory and the Context of Discovery. The Natural History of a Study]." Pp. 26-48 in W kręgu socjologii interpretatywnej-zastosowanie metod jakościowych [In the Circle of Interpretive SociologyThe Application of Qualitative Methods], edited by J. Leoński and A. Kołodziej-Durnaś. Szczecin: USz, Economicus.

Konecki, Krzysztof T. 2007. “Działanie przedsiębiorcze. Auto-praca nad tożsamością a społeczny proces konstruowania motywacji do działania przedsiębiorczego [Entrepreneurial Ac- tivity. Self-Work on Identity and Social Process of Constructing Motivation for Entrepreneurial Activity].” Pp. 72-115 in W kręgu socjologii interpretatywnej. Badania jakościowe nad tożsamościa [In the Circle of Interpretative Sociology. Qualitative Research on Identity], edited by J. Leoński and U. Kozłowska. Szczecin: Usz, Economicus.

Konecki, Krzysztof T. 2008. "Zarządzanie talentami - zarządzanie lamentami, czyli jak rozwija się geniusz? [Talent Management-Management of Lamentations, or How Does Genius Develop?]." Pp. 411-427 in Problemy socjologii gospodarki [Problems in Economic Sociology], edited by S. Banaszak and K. Doktór. Poznan: Wydawnictwo Wyższej Szkoły Komunikacji i Zarządzania.

Lyman, Stanford. 2000. "Accounts: Roots and Foundations." Pp. 7-13 in Encyclopedia of Criminology and Deviant Behavior, edited by C. D. Bryant. Philadelphia: Brunner-Routledge.

McCarthy, Doyle E. 1989. "Emotions and Social Things: An Essay in the Sociology of Emotions." Pp. 51-72 in The Sociology of Emotions, edited by D. Franks and D. McCarthy. Greenwich, CT: JAI Press.

Merton, Robert K. 1968. Social Theory and Social Structure. New York: Free Press.

Minor, William W. 1981. “Techniques of Neutralization: A Reconceptualization and Empirical Examination." Journal of Research in Crime and Delinquency 18(2):295-318.

Nelson, (Adie) E. D. and Ronald D. Lambert. 2001. "Stick, Stones and Semantics: The Ivory Tower Bully's Vocabulary of Motives." Qualitative Sociology 24(1):83-106.

Savickas, Mark L. 2005. "The Theory and Practice of Career Construction." Pp. 42-70 in Career Development and Counseling, edited by S. D. Brown and R. W. Lent. New Jersey: John Wiley \& Sons.

Savickas, Mark L. 2011. Career Counseling. Washington, DC: American Psychological Association.

Scheff, Thomas J. 1984. Being Mentally Ill. Piscataway: Aldine Transaction.

Scheff, Thomas J. and Suzanne Ratzinger. 1991. Emotions and Violence. Lexington: Lexington Books.

Shaw, Clifford R. 1930. The Jack-Roller: A Delinquent Boy's Own Story. Chicago, London: Chicago University Press. 
Shaw, Clifford R. 1931. The Natural History of a Delinquent Career. Chicago: Chicago University Press.

Shott, Susan. 1979. "Emotions and Social Life: A Symbolic Interactionist Analysis." American Journal of Sociology 84(6):1317-1334.

Strauss, Anselm L. 1977. Mirrors and Masks: The Search for Identity. London: Robertson \& Co.

Strauss, Anselm L. 1987. Qualitative Analysis for Social Scientists. Cambridge: Cambridge University Press.

Strauss, Anselm L. and Juliet Corbin. 1990. Basics of Qualitative Research: Grounded Theory Procedures and Techniques. Thousand Oaks, CA: Sage.
Strauss, Anselm L. and Juliet Corbin. 1994. "Grounded Theory Methodology: An Overview." Pp. 273-285 in Handbook of Qualitative Research, edited by N. K. Denzin and Y. S. Lincoln. London: Sage.

Strauss, Anselm L. and Juliet Corbin. 1998. Basics of Qualitative Research: Techniques and Procedures for Developing Grounded Theory. Thousand Oaks, CA: Sage.

Sykes, Gresham M. and David Matza. 1957. "Techniques of Neutralization: A Theory of Delinquency." American Sociological Review 22(6):664-670.

Thrasher, Frederick M. 1927. The Gang: A Study of 1313 Gangs in Chicago, Ill. Chicago: University of Chicago Press.

\section{Citation}

Dymarczyk, Waldemar. 2020. "Spatial and Temporal Dilemmas of Managers and Entrepreneurs. The Reconstruction of Neutralization Techniques." Qualitative Sociology Review 16(4):36-51. Retrieved Month, Year (http://www.qualitativesociologyreview. org/ENG/archive_eng.php). DOI: http://dx.doi.org/10.18778/1733-8077.16.4.03 